\title{
Identifikasi Kedalaman Laut (Bathymetry) berdasarkan Warna Permukaan Laut pada Citra Satelit menggunakan Metode ANFIS
}

\author{
Diwan Mukti Pambuko, Jondri, Rian F. Umbara \\ Departemen Sains, Fakultas Teknik Universitas Telkom \\ Jln Telekomunikasi Terusan Buah Batu Bandung \\ e-mail: jdn@ittelkom.ac.id
}

\begin{abstract}
ABSTRAK
Kedalaman laut (bathymetry) memberikan berbagai informasi penting mengenai suatu area laut. Selain untuk navigasi pelayaran, kedalaman laut juga berguna dalam pemanfaatan sumberdaya alam, sistem peringatan dini dan simulasi dampak dari bencana. Pengukuran kedalaman laut bisa dilakukan manual dengan menggunakan kapal, namun dibutuhkan waktu yang sangat lama. Kebutuhan informasi yang semakin cepat mengenai informasi bathymetry menuntut pengembangan sistem pengukuran manual dengan memanfaatkan teknologi lain seperti penginderaan jarak jauh melalui satelit. Warna permukaan laut apabila dilihat pada gambar satelit memiliki gradasi warna sebagai akibat dari pantulan cahaya pada kedalaman laut yang berbeda-beda. Dengan mengetahui kedalaman sebenarnya pada sebuah area laut dan mengetahui warna permukaan pada posisi tersebut dapat dibuat sebuah sistem yang bisa mengidentifikasi kedalaman laut pada posisi tertentu dari warna pada permukaan laut tersebut. Sistem yang dibangun ini menggunakan data kedalaman laut hasil pengukuran manual dan dipadukan dengan data gambar satelit pada posisi yang sama. Kemudian dilakukan proses learning menggunakan teknik Neuro-Fuzzy dengan metode ANFIS (Adaptive Neuro-Fuzzy Inference System) dengan kinerja model identifikasi dapat diketahui dari nilai MAPE (Mean Absolute Percentage Error) dan MSE (Mean Square Error). Hasil dari pembuatan model identifikasi, diperoleh sistem yang dapat melakukan identifikasi sangat baik dengan error yang diperoleh pada saat proses pengujian sebesar MAPE $9.0024 \%$ dan MSE 0.0034 .
\end{abstract}

Kata kunci: bathymetry, citra satelit, neuro-fuzzy, ANFIS.

\section{ABSTRACT}

Seadepth (bathymetry) provide variety important information about the sea area. In addition to the shipping navigation, sea depth also useful in natural resources utilization, early warning systems and impact simulation of the disaster. Ocean depth measurements can be done manually by boat, but it takes very long time. The very fast information needs about bathymetry data require to develop the manual measurement by utilizing other technologies such as remote sensing via satellites. Sea surface colour when seen in satellite images have colour gradations as a result of the light reflecting by variation of ocean depths. By knowing the exact depth of the sea in an area and know the surface color at that position can be created a system that can identify the depth of the sea at a certain position from its sea surface colors. The system is constructed using the data results from ocean depth manual measurements and combined with satellite image data in the same position. Then learn that combined data using Neuro-Fuzzy technique with ANFIS (Adaptive Neuro-Fuzzy Inference System) methods creating the identification model with performance can be determined from the value of MAPE and MSE. Results of modeling identification, obtained system that can perform identification very well with the error obtained during the testing process by MAPE 9.0024\% and MSE 0.0034 .

Keywords: bathymetry, satellite imagery, neuro-fuzzy, ANFIS 


\section{Pendahuluan}

Perkembangan teknologi yang sangat cepat diiringi dengan berbagai penemuan baru di berbagai bidang mendorong manusia untuk selalu mengaplikasikan teknologi kedalam setiap aspek kehidupan.Dalam keperluan navigasi misalnya, dengan menggunakan peta citra satelit,informasi posisi yang disajikan lebih real jika dibanding peta buatan karena memberikan gambaran mengenai kondisi asli dari permukaan bumi dalam peta tersebut.

Teknologi gambar satelit menyajikan bentuk morfologi permukaan bumi yang bisa dilihat secara langsung. Berbeda untuk lautan, gambar satelit jika dilihat secara langsung tidak menampilkan bagaimana bentuk morfologi dasar laut, namun cukup memberikan informasi bagaimana bentuk dasar laut dibawahnya. Bila diperhatikan, permukaan laut pada gambar satelit memiliki warna yang berbeda-beda. Perbedaan warna ini muncul sebagai akibat dari pantulan cahaya pada permukaan laut dengan kedalaman yang berbeda beda.

Pengukuran kedalaman laut bisa dilakukan manual dengan menggunakan kapal, namun dibutuhkan waktu yang sangat lama. Menurut Mineart dan Gottshll [8], untuk mengukur kedalaman seluruh kedalaman laut dibumi secara manual akan memakan waktu pengukuran hingga 200 tahun. Oleh karena itu dibutuhkan sistem yang bisa menggantikan pengukuran manual dengan memanfaatkan gambar yang diambil oleh satelit. Sistem yang dibangun ini menggunakan data kedalaman laut hasil pengukuran manual dari kapal maupun unit pengukuran manual lainya. Kemudian data tersebut dipadukan dengan data gambar satelit pada posisi yang sama. Setelah diperoleh pasangan data kedalaman dan warna permukaan dilakukan proses learning menggunakan teknik Neuro-Fuzzy dengan metode ANFIS.

Kedalaman laut memberikan berbagai informasi penting mengenai apa yang bisa dimanfaatkan dari laut tersebut. Selain untuk navigasi pelayaran yang berkaitan dengan keselamatan pelayaran, kedalaman bisa memberi informasi sebaran makhluk hidup yang tinggal didalamnya. Menurut Mineart dan Gottshll [8], pengukuran kedalaman laut juga berguna untuk peringatan dini terhadap bencana, seperti Tsunami yang bisa dilakukan proses simulasi untuk mengetahui bagaimana akibat yang ditimbulkan. Hal ini sangat bermanfaat untuk negara yang memiliki lautan yang luas seperti Indonesia, yang merupakan negara kepulauan terbesar di dunia.

Penelitian tentang morfologi dasar laut dari warna permukaan telah dilakukan oleh Chuanmin [3] pada area Sand Ridge di West California, USA. Kemudian penelitian lebih lanjut mengenai identifikasi kedalaman laut menggunakan citra satelit telah dilakukan oleh Corruci et al [2] pada citra multispectral highresolution area laut Castiglione della Pescaiadi Grosseto, Italia. 
Pada tulisan ini akan dibahas model identifikasi kedalaman suatu area laut berdasarkan warna permukaanya dengan memperhatikan kondisi permukaan laut pada saat citra diambil oleh satelit dengan mengimplementasikan metode ANFIS dan menganalisis parameter yang digunakan sertakinerja sistem menggunakan ANFIS.

\section{Metode Penelitian}

Bathymetry adalah studi tentang kedalaman air, baik dasar sungai danau maupun laut. Bathymetry digunakan untuk mendukung keselamatan navigasi pelayaran baik permukaan maupun sub-permukaan. Pada awalnya pengukuran bathymetry dilakukan pengukuran secara manual dengan menggunakan tali dan beban.Teknik ini tidak akurat dan efisien karena hanya bisa mengukur satu titik pada satu satuan waktu dan posisi titik beban terhadap kapal dipengaruhi oleh pergerakan kapal. Saat ini pembuatan data bathymetry menggunakan echosounder (sonar) yang dipasang pada kapal dilakukan berdasarkan jumlah waktu yang diperlukan suara atau cahaya untuk melakukan perjalanan melalui air, memantul kembali di dasar laut, dan melakukan perjalanan kembali ke permukaan. Menurut Thurman [11] satelit bisa digunakan untuk pengukuran bathymetry, satelit radar memetakan topografi dasar lautan dengan mendeteksi variasi halus dipermukaan laut yang disebabkan oleh tarikan grafitasi dari pegunungan bawah laut maupun energy endogen lainya.

\section{Penginderaan jauh}

Pengideraan jauh merupakan ilmu dan teknik untuk memperoleh informasi tentang suatu obyek, daerah atau fenomena, melalui analisis data yang diperoleh dengan suatu alat tanpa kontak langsung dengan obyek yang dikaji. Citra satelit merupakan citra hasil perekaman gambar jarak jauh yang diperoleh melalui satelit.Hasil dari perekaman sangat dipengaruhi oleh kemampuan satelit sebagai alat pengambil gambar. Berdasarkan Lillesand et al [6], gambar yang dihasilkan dari perekaman satelit juga berbeda-beda, sesuai dengan jenis sensor yang dimiliki oleh satelit perekam.

\section{Sistem Informasi Geografis}

Sistem informasi geografis merupakan penyajian informasi geografis ke dalam bentuk media yang mudah dimengerti oleh manusia. Salah satu penyajianya adalah bentuk penyajian data dalam digital elevation model. Digital Elevation Model (DEM) merupakan suatu representasi digital dari topografi permukaan tanah. Menurut Prahasta [9], DEM berisi data ketinggian maupun kedalaman hasil pengukuran langsung maupun perkiraan.

Sistem koordinat dinyatakan juga sebagai posisi spatial, memiliki makna posisi blok-blok pada suatu bidang dengan satuan tertentu. Sistem koordinat membagi sebuah bidang kedalam bagian kecil dengan bentuk tertentu. Kemudian diberikan nama pada setiap bagian untuk memudahkan mengetahui posisi letak pada bidang tersebut. 


\title{
Neuro-Fuzzy
}

Neuro-fuzzy merupakan penggabungan dari dua metode yaitu Sistem fuzzy dan Jaringan Syaraf Tiruan. Kedua metode ini memiliki cara kerja dan proses tersendiri yang berbeda namun bisa dipadukan. Hasil dari penggabungan kedua metode ini adalah suatu metode gabungan yang lebih baik dari kedua metode ini jika berjalan masing-masing.

Sistem Fuzzy memiliki keunggulan dalam proses penalaran untuk proses pengambilan keputusan. Namun terdapat kekurangan yaitu aturan fuzzy harus sudah diketahui oleh sistem sebelum sistem berjalan. Dengan kata lain sistem fuzzy tidak bisa menentukan aturan dari data dengan metode learning. Jaringan Syaraf Tiruan memiliki kemampuan untuk melakukan proses learning tetapi tidak memiliki kemampuan penalaran. Berdasarkan Suyanto [10], dengan menggabungkan Sistem Fuzzy dan Jaringan syaraf tiruan diperoleh sebuah sistem yang bisa melakukan penalaran dan membangun sendiri aturan dengan melakukan learning data.

\begin{abstract}
ANFIS
Adaptive neuro fuzzy inference system (ANFIS) merupakan neuro fuzzy hybrid dengan menggabungkan jaringan syaraf tiruan dengan sistem fuzzy inferensi Sugeno. Merujuk Kusumadewi et al [5], ANFIS adalah sebuah metode yang secara fungsional sama dengan fuzzy rule base model sugeno, dimana dalam penyetelan aturanya digunakan algoritma pembelajaran terhadap sekumpulan data.

Proses adaptasi yang terjadi dalam sistem ANFIS dikenal juga dengan pembelajaran. Parameter-parameter ANFIS (baik premise maupun consequent) Selama proses belajar akan diperbaharui menggunakan metode pembelajaran. Metode pembelajaran yang digunakan dalam sistem ANFIS adalah algoritma pembelajaran hibrid. Algoritma ini terdiri dari dua bagian yaitu bagian arah maju dan bagian arah mundur. Pada bagian arah maju, proses adaptasi dilakukan menggunakan metode Least Square Estimator dan terjadi pada parameter consequent. Berdasarkan Suyanto [10], pada bagian arah mundur, proses adaptasi dilakukan menggunakan metode gradient-descent dan terjadi pada parameter premise.
\end{abstract}

\section{Kinerja}

Menurut Markidadis et al [7], MAPE (Mean Absolute Percentage Error) merupakan ukuran ketepatan relatif yang digunakan untuk mengetahui persentase penyimpangan hasil prediksi, untuk kasus prediksi, sistem dinyatakan memiliki kinerja baik apabila memiliki nilai MAPE dibawah $20 \%$ dan sangat baik apabila dibawah $10 \%$. Berdasarkan Zainun et al [12], SSE (Sum Square Error) merupakan penyimpangan kuadrat prediksi dalam unit yang sama pada data, dengan menjumlah nilai square error (penyimpangan) seluruh hasil prediksi. Merujuk pada Markidadis et al [7], dengan merata- 
ratakan kuadrat error (penyimpangan semua prediksi) tersebut diperoleh nilai MSE (Mean Square Error).

\section{Hasil dan Pembahasan}

\section{Rancangan Sistem}

Dari permasalahan yang telah dibahas sebelumnya, akan dibuat sebuah sistem yang bisa mengidentifikasi kedalaman laut dengan melihat warna permukaanya. Dari data kedalaman yang telah diperoleh dari hasil pengumpulan dengan survey laut dan citra satelit yang diperoleh dari penginderaan jarak jauh melalui satelit, akan dilakukan pembuatan model identifikasi kedalaman dengan menggunakan pasangan data warna permukaan dan data kedalaman pada area yang sama.

Sistem yang akan dibangun ini pada intinya memiliki 5 tahap utama yaitu georeference, cropping, preprocesssing, proses learning dan identifikasi. Untuk lebih jelasnya proses keseluruhan sistem seperti diagram alir pada Gambar 1.

Proses dimulai dengan inputan data berupa citra satelit dan data kedalaman. Kemudian kedua data tersebut dipastikan memiliki system koordinat yang sama melalui proses georeference. Selanjutnya dilakukan pemotongan terhadap citra dan data melalui proses cropping dengan menggunakan batas koordinat pemotongan.

Pada hasil cropping dilakukan preprosesing dengan penggabungan data dan citra berdasarkan posisi spatial pada koodinat yang digunakan. Kemudian dilakukan learning menggunakan neuro-fuzzy dengan metode ANFIS dan diperoleh model identifikasi berupa parameter-parameter pada ANFIS. Model identifikasi hasil learning ini bisa digunakan untuk mengidentifikasi kedalaman dari komposisi rgb yang diinputkan dari citra lain.

Data yang akan digunakan pada sistem yang dibangun ini terdiri dari 2 macam data, yaitu data citra dari pengambilan gambar melalui satelit dan data kedalaman yang diperoleh dari hasil pengukuran langsung. Kedua data ini harus memiliki koordinat pada area yang sama. Jika tidak, maka akan terjadi pergeseran letak antara kedalaman pada sistem dan kedalaman sebenarnya yang berakibat pada ketidak akuratan hasil identifikasi.

\section{Hasil Penelitian}

Data yang digunakan untuk membuat model identifikasi adalah area pantai Ewa, bagian selatan pulau Oahu, kepulauan Hawaii. Lokasi ini dipilih karena ketersediaan data, baik data kedalaman laut maupun citra satelit.Kepulauan Hawai merupakan area proyek simulasi penangulangan bencana pantai, oleh 
karena itu terdapat data yang bisa diperoleh untuk penelitian. Data kedalaman diperoleh dari University of Hawaii, hasil pengukuran sistem US Army Corps of Engineer (USACE) periode survey 1994 hingga 2007. Format data yang disediakan berupa blok dengan ukuran blok $5 \mathrm{~m}^{2}$. Sedangkan citra satelit hasil pengambilan citra oleh Digital Globe pada tanggal 30 Januari 2013. Data dan citra disatukan melalui georeferencing dengan menggunakan sistem koordinat WGS_1984.

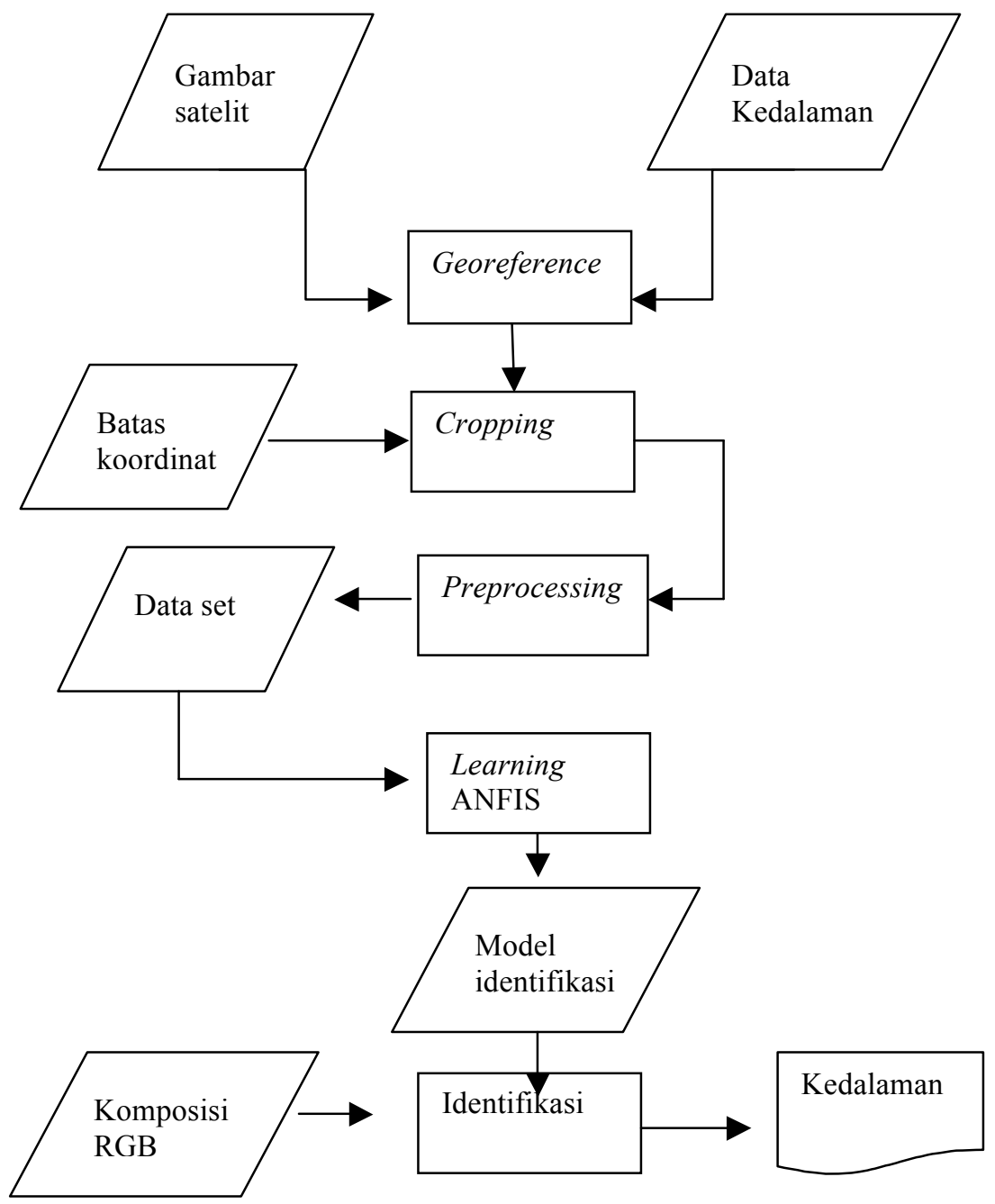

Gambar 1 Diagram alir proses keseluruhan sistem 


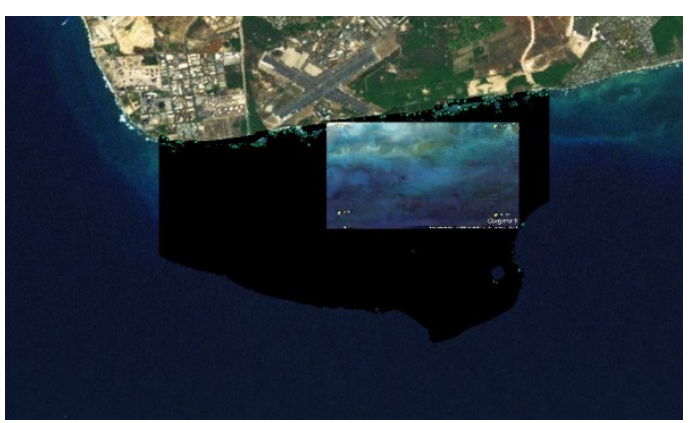

Gambar 2 Hasil proses georeferencing

Gambar 2 menampilkan hasil yang diperoleh dari proses georeferencing, yaitu posisi data kedalaman dan citra satelit yang terletak pada posisi aslinya dalam koordinat bumi. Selanjutnya dilakukan pemotongan data dan citra melalui proses cropping untuk memastikan data dan citra berasal pada area yang sama.

Setelah data dan citra memiliki cakupan area yang sama dilakukan proses penggabungan antara data dan citra.Proses ini diawali dengan melakukan ekstraksi citra satelit dan diperoleh posisi untuk setiap piksel dan komposisi $\mathrm{R}, \mathrm{G}$ dan $\mathrm{B}$. Kemudian dilakukan pengabungan dari posisi data terhadap posisi citra dan hasilnya adalah blok data dan piksel citra dengan posisi yang mendekati dinyatakan melalui distance yang merupakan jarak antara posisi blok data terhadap posisi piksel citra dalam satuan derajat koordinat bumi.

Data hasil preprosesing digunakan sebagai data input proses learning dirubah ke dalam bentuk tabel pasangan input-output. Data pasangan inputoutput kemudian dinormalisasi untuk membuat data kedalam satuan yang sama. Data yang sudah dinormalisasi kemudian dilakukan pembagian menjadi 2, data training dan testing. Kemudian dilakukan beberapa proses pengujian parameter untuk membuat model identifikasi. Berikut hasil yang diperoleh dari pengujian parameter:

Tabel 1 Hasil pengujian pengaruh jumlah rules
\begin{tabular}{|c|c|c|}
\hline $\begin{array}{c}\text { Jumlah } \\
\text { Rules }\end{array}$ & $\begin{array}{c}\text { Rata-Rata } \\
\text { MAPE }\end{array}$ & $\begin{array}{c}\text { Rata-Rata } \\
\text { MSE }\end{array}$ \\
\hline 3 & 10.02836 & 0.00399 \\
\hline 4 & 9.78583 & 0.00379 \\
\hline 5 & 9.01542 & 0.00331 \\
\hline 6 & 9.42558 & 0.00350 \\
\hline 7 & 8.97844 & 0.00326 \\
\hline
\end{tabular}

Dari hasil pengujian terhadap jumlah rules diperoleh hasil terbaik dengan dengan rata-rata MAPE $8.97844 \%$ dan MSE 0.00326 adalah rules dengan jumlah 7 buah. 
Tabel 2 Hasil pengujian pengaruh learning rate

\begin{tabular}{|c|c|c|}
\hline $\begin{array}{c}\text { Learning } \\
\text { Rate }\end{array}$ & $\begin{array}{c}\text { Rata- } \\
\text { Rata } \\
\text { MAPE }\end{array}$ & $\begin{array}{c}\text { Rata- } \\
\text { Rata } \\
\text { MSE }\end{array}$ \\
\hline 0.1 & 9.35982 & 0.00354 \\
\hline 0.01 & 9.47157 & 0.00357 \\
\hline 0.001 & 9.50879 & 0.00360 \\
\hline
\end{tabular}

Dari hasil pada Tabel 2 terlihat bahwa learning rate terbaik adalah 0.1 dengan rata-rata MAPE $9.35982 \%$ dan rata-rata MSE 0.00354 .

Tabel 3 Hasil pengujian pengaruh momentu
\begin{tabular}{|c|c|c|}
\hline Momentum & $\begin{array}{c}\text { Rata- } \\
\text { Rata } \\
\text { MAPE }\end{array}$ & $\begin{array}{c}\text { Rata- } \\
\text { Rata } \\
\text { MSE }\end{array}$ \\
\hline 0.7 & 9.69920 & 0.00374 \\
\hline 0.8 & 9.34234 & 0.00349 \\
\hline 0.9 & 9.29864 & 0.00348 \\
\hline
\end{tabular}

Dari hasil pada Tabel 3 diatas dipilih momentum 0.9 dengan rata-rata MAPE 9.29864\% dan rata-rata MSE 0.00348. Momentum dengan nilai terbesar mempercepat proses training namun belum tentu memberkan hasil training terbaik dengan kemungkinan nilai terbaik terlewati karena bagian update yang terlalu kecil. Sedangkan nilai momentum kecil membuat proses learning lebih lama namun tidak menjamin untuk memperoleh nilai terbaik karena kemungkinan masih terjebak pada minimum lokal.

Tabel 4 Hasil pengujian pengaruh epoh
\begin{tabular}{|c|c|}
\hline $\begin{array}{c}\text { learning } \\
\text { rate }\end{array}$ & $\begin{array}{c}\text { Rata-Rata Epoh } \\
\text { diperlukan }\end{array}$ \\
\hline 0.1 & 21 \\
\hline 0.01 & 20 \\
\hline 0.001 & 31 \\
\hline
\end{tabular}

Dari Tabel 4 dapat diketahui rata-rata jumlah epoh yang dibutuhkan untuk mencapai eror konvergen untuk masing-masing learning rate. Jumlah epoh yang diperlukan untuk mencapai konvergen tidak mencapai maksimal eror yang diset. Penambahan jumlah epoh diatas jumlah yang telah diset yaitu 100 tidak memperkecil nilai eror yang diperoleh, dengan kata lain tidak memperbaiki kinerja sistem.

Dari hasil yang telah diperoleh dari pengujian terhadap pengaruh parameter maka diperoleh parameter terbaik dari proses adalah : jumlah rules 7, 
learning rate 0.1, momentum 0.9. Hasil dari training dari sistem dengan parameter tersebut menghasilkan nilai MAPE 8.7129\% dan MSE 0.0029253. Selanjutnya dilakukan testing terhadap model hasil training dan diperoleh MAPE $9.0024 \%$ dan MSE 0.0034. Nilai output belum menampilkan hasil dalam satuan kedalaman sebenarnya, oleh karena itu diperlukan proses reverse normalisasi.

Tabel 5 Perbandingan output kedalaman terhadap kedalaman sebenarnya

\begin{tabular}{|c|r|r|r|}
\hline No & Target & \multicolumn{1}{c|}{ Output } & \multicolumn{1}{c|}{ Selisih } \\
\hline 1 & -4.79 & -7.14 & 2.35 \\
\hline 2 & -14.39 & -16.43 & 2.04 \\
\hline 3 & -17.42 & -22.92 & 5.50 \\
\hline 4 & -18.49 & -17.36 & -1.13 \\
\hline 5 & -2.97 & -2.77 & -0.20 \\
\hline 6 & -12.54 & -12.74 & 0.20 \\
\hline 7 & -19.42 & -19.74 & 0.32 \\
\hline 8 & -8.58 & -7.63 & -0.95 \\
\hline 9 & -24.51 & -20.03 & -4.48 \\
\hline 10 & -10.48 & -9.30 & -1.18 \\
\hline 11 & -10.43 & -11.00 & 0.57 \\
\hline 12 & -20.35 & -15.93 & -4.42 \\
\hline 13 & -16.74 & -18.54 & 1.80 \\
\hline$\ldots$ & $\ldots$ & $\ldots$ & $\ldots$ \\
\hline 265 & -17.21 & -14.30 & -2.91 \\
\hline
\end{tabular}

Dari Tabel 5 dapat dilihat perbedaan antara kedalaman hasil output sistem dengan kedalaman sebenarnya dengan melihat selisihnya. Semakin besar selisih maka kesalahan identifikasi yang dilakukan semakin besar. Untuk melihat perbandingan output kedalaman terhadap kedalaman sebenarnya dari semua data testing dapat dilihat pada Gambar 3 dengan mengurutkan data dari kedalaman yg paling kecil.

Dari Gambar 3 dapat dilihat pola dari kedalaman output (output) telah mampu memenuhi bentuk pola dari kedalaman sebenatnya (target) dengan kesalahan identifikasi sebesar MAPE 9.0024 \% maupun MSE 0.0034.

Model identifikasi yang diperoleh bisa digunakan untuk melakukan identifikasi terhadap citra satelit lain. Model identifikasi tersebut meliputi parameter premise dan konsekuen yang diperoleh dari skenario dengan parameter hasil penentuan dari percobaan yang telah dilakukan. Dengan model identifikasi yang diperoleh dapat juga dilakukan proses identifikasi kedalaman dari komposisi RGB yang diinputkan ke sistem.

Dari proses pengujian terhadap model identifikasi yang telah dibuat, diperoleh nilai kesalahan prediksi MAPE sebesar 9.0024\%. Menurut Zainun et al [12], untuk kasus prediksi sistem dinyatakan memiliki kinerja baik 
apabila memiliki nilai MAPE dibawah $20 \%$ dan sangat baik apabila dibawah $10 \%$.

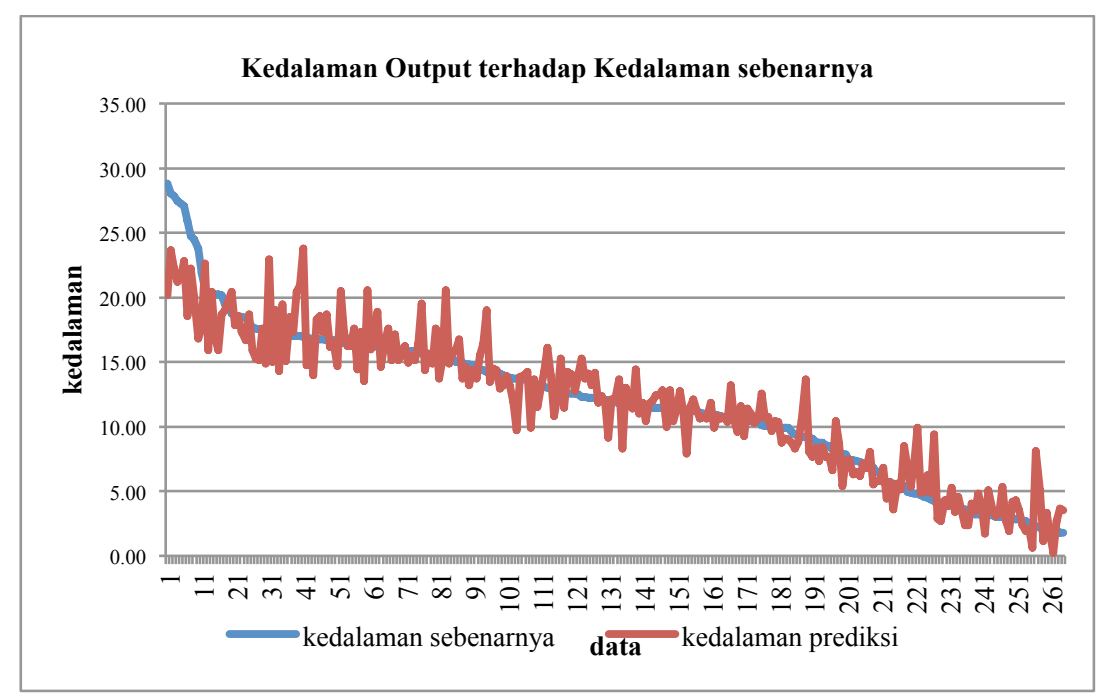

Gambar 3. Perbandingan output kedalaman terhadap kedalaman sebenarnya

Dari ketentuan tersebut maka sistem yang dihasilkan termasuk kedalam kategori sangat baik dengan nilai MAPE $9.0024 \%$. Sementara pada penelitian oleh Isoun et al [4] terhadap area Hawaii diperoleh rata-rata eror 14\%. Untuk penelitian yang telah dilakukan ini tidak dapat dilakukan pembandingan karena perbedaan metode dan teknologi data yang digunakan. Namun dari hasil yang diperoleh dapat digunakan sebagai acuan dalam proses pembuatan model identifikasi.

\section{Simpulan}

Identifikasi kedalaman dari sebuah area laut dengan melihat warna permukaan laut dilakukan dengan menggunakan pasangan data citra satelit dan data kedalaman pada area yang sama. Proses pembuatan model dilakukan dengan melakukan pembelajaran terhadap pola pasangan data warna permukaan dan kedalaman pada posisi warna permukaan laut tersebut.Implementasi penyelesaian pada metode ANFIS dilakukan dengan membentuk pasangan data input-output berupa komposisi R,G,B sebagai input dan kedalaman pada komposisi tersebut sebagai target. Dari percobaan yang telah dilakukan, diperoleh parameter learning terbaik dari skenario yang telah dibuat, learning rate 0.1 , momentum 0.9 , dan jumlah rules 7 , dengan jumlah epoh yang dipilih adalah 100 epoh. Penggunaan parameter terbaik yang diperoleh dari proses pembuatan model identifikasi kedalaman laut berdasarkan warna permukaan, hasil dari training diperoleh nilai MAPE 
8.7129\% dan MSE 0.0029253 , kemudian pada proses testing diperoleh MAPE $9.0024 \%$ dan MSE 0.0034. Sistem identifikasi memiliki kinerja yang sangat baik karena nilai MAPE sistem berada dibawah $10 \%$.

Saran untuk pengembangan penelitian ini yaitu penambahan parameter input selain komposisi warna RGB, penggunaan metode lain untuk proses identifikasi sehingga hasilnya bisa dibandingkan, penggunaan citra satelit pada saat kondisi cuaca tertentuuntuk membandingkan pengaruhnya, penggunaan citra satelit dari perekaman berbagai jenis satelit, sehingga sistem yang dihasilkan bisa menangani hasil rekaman citra oleh satelit lebih beragam, pengembangan kasus untuk pemanfaatan sumberdaya alam khususnya pada area laut.

\section{Daftar Pustaka}

1. Corruci, Linda, Masini, Andrea, 2010., A study on Bathymetry Estimation From High Resolution Multi-Spectral Satellite Images, Proceedings of IEEE GOLD 2010 : IEEE South Italy Geoscience \& Remote Sensing Chapter.

2. Corruci, Linda, Masini, Andrea, Cococcioni, Marco, 2011., Approaching bathymetry estimation from high resolution multispectral satellite images using a neuro-fuzzy technique, Journal of Applied Remote Sensing, Volume 5, Issue 1, pp. 053515-053515-15

3. Hu, Chuanmin, 2008., Ocean Color Reveals Sand Ridge Morphology on the West Florida Shelf, IEEE Geoscience and Remote Sensing Letters.

4. Isoun, E., et al, 2003., Multi-spectral mapping of reef bathymetry and coral cover; Kailua Bay, Hawaii, Springer-Verlag: Coral Reefs, 22: 68-82, DOI 10.1007/s00338-003-0287-4.

5. Kusumadewi, Sri, Hartati, Sri, 2010, Neuro-Fuzzy: Integrasi Sistem Fuzzy dan Jaringan Syaraf Edisi 2, Graha Ilmu, Yogyakarta.

6. Lillesand, T. M., Kiefer, R. W., 1994. Remote Sensing and Image Interpretation, John Wiley \& Sons, New York.

7. Markidakis, Spyros et all.,1999, Metode dan Aplikasi Peramalan, Binarupa Aksara, Jakarta.

8. Mineart, Gary M., Gottshall, CDR Eric, 2005. Bathymetry from space: Technologies and Applications, IEEE Ocean Proceeding 
9. Prahasta, Eddy, 2002, Sistem Informasi Geografis Konsep-Konsep Dasar (Prespektif Geodesi dan Geomatika) Penerbit Informatika, Bandung.

10. Suyanto, 2008, Soft Computing : Membangun Mesin Ber-IQ Tinggi, Penerbit Informatika, Bandung.

11. Thurman, H. V. 1997, Introductory Oceanography, Prentice Hall College, New Jersey.

12. Zainun, N. Yasmin, Eftekhari, M., 2010. Forecasting low-cost housing demand in urban area in Malaysia using ANN, Challenges, Opportunities and Solutions in Structural Engineering and construction (OTaylor \& Francis Group, London, ISBN 978-0-415-56809-8 